of the occult laws of nature governing farm life. By a knowledge of economic botany he is able to make the most of his soil and crops by a judicious selection of plants best adapted to his farm, both as regards soil and climate.

Insect enemies are becoming more numerous as the country grows older. New insect pests are continually arising, and those that for long years have been branded as "thieves and robbers" in the Old World are being continually introduced. While these insect pests are a constant thorn in the flesh to the illiterate farmer, the scientist is able to ward off their attack, and thus be greatly benefited, personally, by their general depredations. The same is also true of germ diseases, such as pear blight, peach yellows and the like, as such diseases make large crops and correspondingly large prices possible only in the hands of the skilled horticulturalist.

A knowledge of physiology is also of great use to the man who would make the most of the farm. Plant physiology and veterinary science are branches of farm economy the importance of which is just beginning to be realized.

And last but not least the educated farmer is a man able to devote much time to the literature of the day. In the farm journals he finds the latest and best ideas of the most progressive men which aid him in thinking and planning for himself, and in turn contributing his mite to the agricultural press.

There is an old saying that education drives men from the farm, but we are just coming to recognize the fact that the average college graduate with a scientific education, finds on the farm an opportunity for original investigation and financial success fully equal or exceeding that in any other vocation. This assertion finds abundant proof in the lives of many practically scientific farmers, and also in the fact that numerous college men are going onto farms every year, who become enthusiastic and devoted agriculturalists that hold their farms in the highest esteem.

We are rapidly approaching the time when a "survival of the fittest" basis must characterize the life of the American farmer. In times past our vast areas of tillable land have formed a basis for almost exhaustless agricultural operations. This state of affairs, coupled with the fact that a man failing in all other vocations can make a living on a farm-provided he possesses only the power of mimicry born of ignorance-is sufficient to explain the low intellectual standard on the farm, and also accounts for the manner in which the cheap farmer is universally held in derision.

Severe competition on the farm is already being felt and the poorest managers are continually going to the wall. We forget that it is the man that hampers the agricultural profession and not the farm that grinds its occupant.

The educated agriculturalist is slowly but surely driving the uneducated and unthinking man from the field. With the retirement of every quack and the corresponding: advent of the thinking man on the farm arena, is elevated the whole agricultural profession, which is thus brought one step nearer its true position that it justly held in Roman times - the foremost rank of all the world.

The uneducated man goes onto the farm as a last resort. His other resources have either failed or never materialized, and he is compelled to eke out an existence in what he considers a belittling business. On the contrary, the educated man goes onto his farm out of love for his chosen vocation, respect for his farm and faith in his ability to make the farm an unqualified success. He makes his home a model of comfort and convenience that may well excite the envy and admiration of his most wellto-do city brother. For besides the comforts and luxuries within his reach he enjoys absolute peace and seclusion unknown to city life.

Let us have more men with active brains and more culture and refinement in rural life, and we will hear less of unproductive and abandomed farms and less of farmers' boys going to the city for a more congenial business.

\section{THE I: $\because$ :}

BY OLIVE THORNE MLLLER, BROOKLYN, N. Y.

ONE never looks for eccentricities in the robin family, and great was my surprise at the curious conduct of a pair who came under my observation last Summer. I fear their heads were turned by a disappointment to begin with, for they successfully raised a brood of three in a nest under the edge of the veranda roof, and never displayed any vagaries. When the young birds had flown, the deserted nest was removed, because the veranda was to be painted.

On beginning to think of a second brood, they seemed greatly disturbed at the loss of their nest. They had fixed their hearts on that veranda, and for days they could not give it up, and judging from subsequent events I am inclined to think it seriously unsettled them. They inspected every corner, the top of the columns where the nest had been, the support that held a string of corn for the squirrels, a peg driven in under the roof, the niche over the door, the chinks in the lattice,-none of them were satisfactory, and at last they turned their attention elsewhere.

They did not seem to please themselves, although several times we thought they were settled, and one day it became plain that trouble was brewing between them. Like some bigger folk, they had let their mutual calamity sour them toward each other.

Madam had plainly selected for the new homestead a delicate crotch on a irail branch, close beside the veranda where her heart was. This was the first sign of aberration of mind, for it was an absurd choice, ludicrously inadequate to the demands of a robin's nest, and her sensible little spouse refused to consent, but kept himself out of sight and hearing of such folly.

But she had made her decision; she began to build. The first I saw of her, she came with a beakful of dried grass from the lawn, flew up to the selected branch near the tree, and then ran out on it as on a path, till she reached the crotch. I was delighted. I had long wished to watch the whole process of building a nest, and here I saw my chance. It was in plain sight and the robins had learned not to fear us. I placed myself, and the show began.

The bird came with her mouthful of grass, as I said, and when she arrived at the spot, she simply opened her beak and let her load fall. Some of it lodged in the crotch, but most of it fell to the ground. Down she went at once and gathered it up, returned by her pretty path,and repeated the performance!

Then a kind bird-lover from the house scattered some short pieces of string on the walk for her use. She saw them at once, came down, gathered up an enormous beakful, returned to her branch, and dropped them as she had the grass. Hardly a particle lodged, and she went down and brought it up again; even a third time she repeated the operation.

By this time it was plain to lookers-on that her heart was not in her work, that she was merely "pretending" to build, that, in fact, she was in a "tiff," undoubtedly with her mate. But she went through all the motions so charming to see when done in earnest. She settled herself in the crotch as though it were a nest. She tried it this side and that, and she made great pretence of having 
definitely settled the matter. Meanwhile her mate, who had still a good deal of care of three dapper young robins in the evergreens (their first family), had apparently selected a heavier crotch in a better place, and he busied himself about that spot, not making any attempt to build, but merely showing his preference.

Madam would not look at him. Finally while she was absent, he came down to a vase on the lawn. a favorite perch of his, where he had sung away many a twilight hour, and began a very low, sweet song. It was alluring; hard indeed must be the heart that could resist it.

She did come, but she did not join him on the vase. She had another load of material, and flew at once to her chosen tree. He stopped singing and looked ather. She alighted and ran out on the branch as she had done before, and, as before, the material she had collected fell to the ground. Then she flirted herself over the crotch in a petulant way that tumbled off every scrap that had lodged there. Plainly she was "mad." and did not seriously intend to build there at all.

After this display she flew away, and her observer on the vase went to the ground where he could look through the passage she had taken. Presently the captious little dame returned with an empty beak, and alighted near him on the lawn. To our amazement he instantly ran away several feet, then paused. She advanced toward him, and he ran farther, keeping always a few feet from her. It actually appeared as if he were on the defensive.

This sort of performance went on for some time. Occasionally both were out of sight behind the low-growing evergreens, then both would return and go on as before, he never letting her get nearer to him than five or six feet. It was painful to see this bad state of things in our heretofore amiable couple, and we sorely regretted having torn down the nest.

It is one of the maddening things to the bird-student that he cannot keep his game always in sight. No matter how great the crisis in their lives, nor how absorbing his interest, a flit of the wings carries them out of sight in a moment. Then again they are such distressingly early risers. If the student tear himself away from his pillow before the sun shows his face, he will find bird-life in full blast. Before it is light enough to see well, their day of work and play is begun. We shall never thoroughly know the feathered folk till we rise at their uncanny hour and learn to fly!

Before we got the robin fairly in view again - probably in those tantalizing morning hours-their difficulties had straightened out, and building was going on seriously in a maple tree a little down the road, quite near the other, but out of sight from the veranda.

Two or three weeks passed in peace, and we hoped the robin troubles were over. Every day we saw the hardworking sire, followed around by his three young folk, as big as he was, calling and teasing for food.

Then one evening the robin treated us to a strange performance. He stood on the ground in the middle of the carriage way, crouched, so that he almost rested on the gravel, his head sunk between his shoulders, and looking as if he were at his last gasp. But he was uttering low notes, and we listened. It was a constant repetition of the queer unmusical sort of "que-e-e" with which many robins end their song. This is neither a trill nor a distinct note, but a sound as if the bird had tried to reach a high note and the voice had broken.

The bird repeated it again and again, and with varied inflections and movement. Plainly he was practising it. What could be his object? and why that unnatural attitude? Had he been crazed by his troubles, and was he a candidate for the lunatic asylum? or was he perchance a genius, evolving a new song for the robin tribe? Evi- dently he was bound to evolve something, for he practised without ceasing.

After awhile he moved a little so that his tail-still resting on the ground-was deflected to one side, in a very unnatural position, and there he stood motionless for half an hour or more, still constantly making the strange noises. All this time we had not been positive of his identity, but now he turned his head up as though addressing some divinity in the tree with his grotesque strains. He was not ten feet from us, and it was eight o'clock and perfectly light, so that we saw him distinctly. Just as we were concluding that some accident must have befallen him and we ought to go down to see, he suddenly straightened himself up on his legs, shook himself out, and sang out loud and clear his regular song. That made it certain that it was our friend of the maple tree, and we were fearful that his mate being at last settled and in her right mind, he had himself broken down. Our host, however, refused to take this desponding view. He insisted that the bird felt within him the stirrings of genius, and that he was founding a race of robins with a new song.

Certain it is that he kept up the strange practisings evening after evening, though never again on the ground. Madam, his spouse, sometimes came down and looked at him, as if to make up her mind whether he was simply unfortunate and to be pitied, or whether he were vicious in deliberately violating all robin traditions, and she ought to discipline him. Apparently she was unable to decide, for she returned to her undoubted duty, and he kept up his droll entertainment till the next instalment of his family came on to demand all his time and strength, and robin music ceased altogether.

At the end of July I left the scene of this robin eccentricity, but my comrade, who remained, heard so late as the middle of October, the same sort of performance going on among thick berry-bushes, at some distance from the house, and on starting up the bird she found it to be a robin.

Could it be the same bird? And shall we have a new sort of robin music next spring?

BIOLOGICAL NOTES FROM NEW ZEALAND.-II.

BY GEO. M. THOMSON, DUNEDIN, N. Z.

IN a previous paper (Science, Vol. XX., p. 323), attention was draw to the fact that the plants of New Zealand are nearly destitute of all such structures as are correlated with the presence of mammalia. A priori this is what might have been expected in a country in which there were no indigenous mammals. Those plants which have defensive structures, such as spines, prickles, etc., and those whose seeds or fruits are fitted for adhering to the coats of passing animals belong in almost every case to species having a wide range outside of New Zealand, the inference being that the characters referred to have been developed outside the New Zealand region, and that such species have been introduced into these islands at a comparatively recent period.

Another interesting feature in the flora is the relation existing between the flowering plants and the various agencies which are necessary for fertilizing the blossoms. Visitors to these islands are usually struck with the prevailing dark hue of the evergreen vegetation and the apparent absence of flowers. Associated with this is a corresponding absence of conspicuous insects,-especially large Lepidoptera and Hymenoptera,-which are such active agents in this work in most other parts of the world. While it is true that there are a few species of flowering plants of exceptional beauty, such as Clianthus puniceus and the splendid white Clematis ( $C$. indivisa, yet the general verdict is correct that the flowers of the 